\title{
Aldosterone Up-regulates Production of Plasminogen Activator Inhibitor-1 by Renal Mesangial Cells
}

\author{
Jun Yuan, Ruhan Jia* and Yan Bao \\ Department of nephrology, Renmin Hospital of Wuhan University, Wuhan, China
}

Received 28 June 2006, Accepted 29 September 2006

\begin{abstract}
In vivo studies have demonstrated that aldosterone is an independent contributor to glomerulosclerosis. In the present study, we have investigated whether aldosterone itself mediated glomerulosclerosis, as angiotensin II (Ang II) did, by inducing cultured renal mesangial cells to produce plasminogen activator inhibitor-1 (PAI-1), and whether these effects were mediated by aldosterone-induced increase in transforming growth factor $\beta_{1}$ (TGF- $\left.\beta_{1}\right)$ expression and cellular reactive oxygen species (ROS) activity. Quiescent rat mesangial cells were treated by aldosterone alone or by combination of aldosterone and spironolactone, Ang II, neutralizing antibody to TGF- $\beta_{1}$ or antioxidant $\mathrm{N}$ acetylcysteme (NAC). This study indicate that aldosterone can increase PAI-1 mRNA and protein expression by cultured mesangial cells alone, which is independent of aldosterone-induced increases in TGF- $\beta_{1}$ expression and cellular ROS. The effects on PAI-1, TGF- $\beta_{1}$ and ROS generation were markedly attenuated by spironolactone, a mineralocorticoid receptor antagonist, which demonstrate that mineralocorticoid receptor (MR) may play a role in mediating these effects of aldosterone.
\end{abstract}

Keywords: Aldosterone, Mineralocorticoid receptor, Plasminogen activator Inhibitor-1, Reactive oxygen species, Transforming growth factor $\beta_{1}$

\section{Introduction}

Recently, extensive clinical and animal model studies indicate that aldosterone is an independent contributor to the progression of renal injury, and mineralocorticoid receptor (MR) antagonists can markedly ameliorate renal injury (Brown et al., 2000; Miric et al., 2001; Feria et al., 2003; Sato et al., 2003;

*To whom correspondence should be addressed.

Tel: 86-27-88041911 ext. 2149; Fax: 86-27-88327525

E-mail: stfgp@126.com
Fujisawa et al., 2004; Hollenberg, 2004; Nishiyama and Abe, 2004). Several studies have indicated that aldosterone can be synthesized by rat glomerular mesangial cells (Lai et al., 2003; Nishiyama et al., 2005; Nishiyama and Abe, 2006) and mineralocorticoid receptor are highly expressed in rat glomerular mesangial cells (Lai et al., 2003; Nishiyama et al., 2005; Nishiyama and Abe, 2006). These studies suggest that locally produced aldosterone can act on mesangial cells, the key producers of extracellular matrix (ECM) in progressive glomerulosclerosis.

The amount of ECM deposited in the kidney depends on the balance between the synthesis and degradation of ECM (Eddy, 2000). Although enhanced ECM synthesis has been demonstrated to contribute to ECM accumulation, decreased degradation of the ECM could also play an important role in matrix accumulation and glomerulosclerosis. Two major ECM protease systems, plasminogen activator (PA)/plasmin/ plasminogen activator inhibitors (PAI) system and matrix metalloproteinases (MMP)/tissue inhibitors of matrix metalloproteinases (TIMP) system, are interrelated and involved in matrix degradation (Mignatti, 1995; Schnaper, 1995; StetlerStevenson, 1996). Plasminogen activator inhibitor-1 (PAI-1), a principal inhibitor of plasminogen activators (tissue-type plasminogen activator and urokinase-type plasminogen activator) (Vaughan, 2001; Eddy, 2002), can promote glomerulosclerosis by preventing the activation of matrix metalloproteinases (MMPs) and the degradation of ECM by plasminogen activators and plasmin (Vassalli et al., 1991; Eddy, 2002). Recently, several animal experiments have indicated that aldosterone contribution to glomerulosclerosis is partly due to up-regulation of PAI-1 expression, and spironolactone can ameliorate glomerulosclerosis via the inhibition of PAI-1 expression in streptozotocin-diabetic rats (Miric et al., 2001; Fujisawa et al., 2004), 5/6 nephrectomy (Aldigier et al., 2005) and rat kidney radiation model (Brown et al., 2000). Furthermore, levels of PAI-1 correlate significantly with aldosterone concentration during periods of low slat intake (Brown et al., 1998). Despite the implications of the aforementioned studies, there are few studies on the effect of 
aldosterone alone on PAI-1 expression by mesangial cells. Brown et al reported that in cultured human umbilical vein endothelial cells and rat aortic smooth muscle cells, aldosterone itself could not regulate PAI-1 expression, but modulated the effect of angiotensin II (Ang II) on PAI-1 expression (Brown et al., 2000). It is not clear presently whether aldosterone itself mediates glomerulosclerosis, as Ang II does (Kagami et al., 1997), by inducing cultured mesangial cells to produce PAI-1.

Aldosterone also increase transforming growth factor $\beta_{1}$ (TGF- $\beta_{1}$ ) (Juknevicius et al., 2004) and reactive oxygen species (ROS) (Miyata et al., 2005) production in kidney. Both TGF- $\beta_{1}$ and ROS play an important role in renal injury (Lee et al., 2003), and can up-regulate PAI-1 expression in mesangial cells (Jiang et al., 2003; Lee et al., 2005). These reports prompted us to investigate whether the effect of aldosterone on PAI-1 induction is mediated by aldosteroneinduced increases of TGF- $\beta_{1}$ expression and cellular ROS.

Therefore, we plan to verify the hypothesis that aldosteroneinduced PAI-1 expression may be independent of angiotensin II and act through the mediation of mineralocorticoid receptor, and to explore the role of ROS and TGF- $\beta_{1}$ in aldosteroneinduced PAI-1 expression.

\section{Materials and Methods}

Cell culture. The rat mesangial cells line (HBZY-1) purchased from China center for type culture collection (Wuhan, China) was plated in MEM containing 10\% fetal bovine serum (FBS, Gibco), $15 \mathrm{mM} \quad \mathrm{N}$-2-hydroxy-ethylpiperazine-N-2-ethane-sulfonic acid (HEPES), $20 \mathrm{mM} \mathrm{NaHCO}, 100 \mathrm{U} / \mathrm{ml}$ penicillin, $100 \mu \mathrm{g} / \mathrm{ml}$ streptomycin, and cultured in a humidified atmosphere of $95 \%$ air and $5 \% \mathrm{CO}_{2}$ at $37^{\circ} \mathrm{C}$. Cells were cultured in $100-\mathrm{mm}$ culture dish for western blot measurement, on cover glass coated with polylysine for intracellular ROS measurement, and 6-well culture plate for enzyme-linked immunosorbent assay (ELISA) and Reverse transcriptase polymerase chain reaction (RT-PCR). Near-confluent mesanial cells were incubated with serum-free media for $24 \mathrm{~h}$ to arrest and synchronize the cell growth. After this time period, the media were changed to fresh serum-free MEM containing different concentrations of aldosterone (Sigma) or angiotensin (Sigma) for $24 \mathrm{~h}$. In some experiments, cells were pretreated with $1 \mathrm{nM}$ spironolactone for $3 \mathrm{~h}$ to block mineralocorticoid receptor (MR), or $100 \mu \mathrm{g} / \mathrm{ml}$ neutralizing chicken anti-TGF- $\beta_{1} \operatorname{lgG}$ (R\&D System Inc) for $1 \mathrm{~h}$ to inhibit activity of TGF- $\beta_{1}$, or an antioxidant $\mathrm{N}$ acetycysteme (NAC; Sigma) at $5 \mathrm{mM}$ for $1 \mathrm{~h}$ before the addition of aldosterone. Cells were processed for measurement of ROS level, TGF- $\beta_{1}$ expression, and PAI- 1 mRNA and protein expression at the end of the incubation period as described below.

Reverse transcriptase polymerase chain reaction. RT-PCR was performed to determine the relative quantity of PAI-1 mRNA in mesangial cells, whereas GAPDH mRNA, a housekeeping gene, was used as an internal control. Briefly, total RNA was extracted from mesangial cells with Trizol (Invitrogen Corporation). First- strand cDNA synthesis was reversely transcribed from $2 \mu \mathrm{g}$ of mRNA in transcription buffer and $200 \mathrm{U}$ MMLV reverse transcriptase (Promega) at $42^{\circ} \mathrm{C}$ for $1 \mathrm{~h}$, followed by immediate cooling on ice. PCR amplification was performed using Taq polymerase (Takara) in a total volume of $50 \mu \mathrm{l}$. The upstream and downstream primers for rat PAI-1 mRNA were 5'-GCCTCCAAAGACCGAAATGTG-3' and 5'-GTCGTTGATGATGAATCTGGCTC-3', yielding a $317 \mathrm{bp}$ product, whereas those for GAPDH were 5'-TAGCCCAGGATGC CCTTTAGT-3' and 5'-CCCCCAATGTATCCGTTGTG-3', yielding a 119 bp product. PCR conditions were as follows: 35 cycles, denaturating at $94^{\circ} \mathrm{C}$ for $30 \mathrm{~s}$, annealing at $52^{\circ} \mathrm{C}$ for $60 \mathrm{~s}$ and extending at $72^{\circ} \mathrm{C}$ for $60 \mathrm{~s}$ with initial heating at $94^{\circ} \mathrm{C}$ for $3 \mathrm{~min}$ and final extending at $72^{\circ} \mathrm{C}$ for $10 \mathrm{~min}$. The PCR products were separated by $1.5 \%$ agarose electrophoresis and the band densities. Images were captured, and the signals were quantified in arbitrary units as $\mathrm{OD} \times$ band area using Vilber Lourmat image analysis system (Vilber Lourmat, Marne-la-Vallee Cedex 1). The results are expressed by density ratios to GAPDH.

Intracellular ROS. The intracellular formation of ROS was detected in confocal microscopy by using the fluorescent probe 5-(and-6)-chloromethyl-2',7'-dichlorodihydrofluorescein diacetate (CM- $\mathrm{H}_{2}$ DCFDA; Molecular Probes Inc.), as described by Lee et al. (2005). In brief, cover glasses of confluent cells in different groups were washed with dulbecco's phosphate-buffered saline (PBS) and incubated in the dark for $45 \mathrm{~min}$ in PBS containing $10 \mathrm{mM} \mathrm{CM}$ $\mathrm{H}_{2}$ DCFDA at $37^{\circ} \mathrm{C}$. Subsequently, the cells were washed third with Dulbecco's phosphate-buffered saline (PBS) to remove any excess dye. $\mathrm{CM}-\mathrm{H}_{2} \mathrm{DCFDA}$, which is oxidized to the highly fluorescent 2',7'-dichlorofluorescein (DCF) by $\mathrm{H}_{2} \mathrm{O}_{2}$ or $\mathrm{OH}^{-}$, was used as a marker for ROS generation. Cells were viewed by using $40 \times 1.4$ objective lens equipped with a laser scanning confocal attachment (Leica). CM- $\mathrm{H}_{2}$ DCFDA was excited with the 488-nm line of an argon/krypton mixed gas laser. Emission was collected with a 510$\mathrm{nm}$ long pass filter. Images were obtained using the identical microscope settings, such as contrast and brightness, for all samples. The fluorescent images were quantified by Leica confocal software program.

ELISA assay. TGF- $\beta_{1}$ and PAI- 1 protein in conditioned media was quantitatively measured by ELISA method according to the manufacturer's instructions to the TGF- $\beta_{1}$-ELISA detection Kit (Boster) and PAI-1-ELISA detection Kit (Sunbiotech) respectively.

Statistical analysis. All results are expressed as means \pm standard deviation (SD). Analysis of variance was used to assess the differences between multiple groups. If the $\mathrm{F}$ statistics was significant, the mean values obtained from each group were then compared by Fisher's least significant difference method. $\mathrm{P}$ value $<0.05$ was used as the criterion for a statistically significant difference.

\section{Results}

Effect of aldosterone and angiotensin II on PAI-1 mRNA and protein espression by mesangial cells. Mesangial cells were exposed to aldosterone (100 nM), Ang II (100 nM) or 
(A)

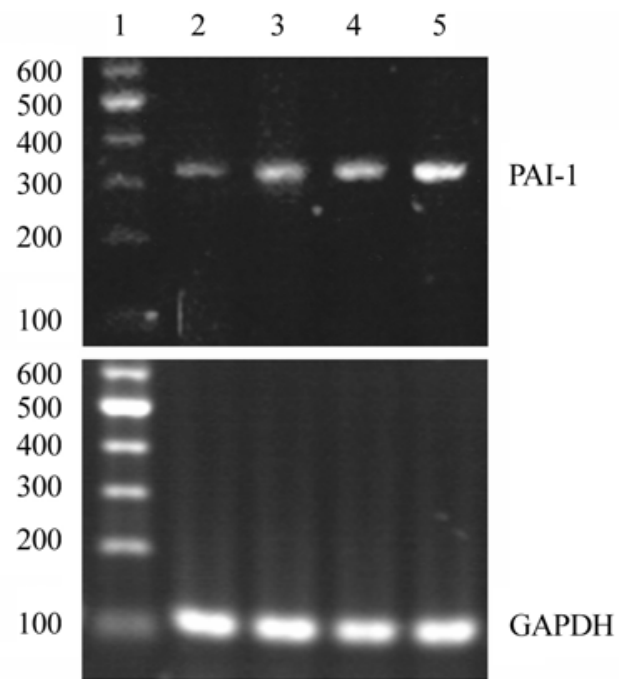

(B)

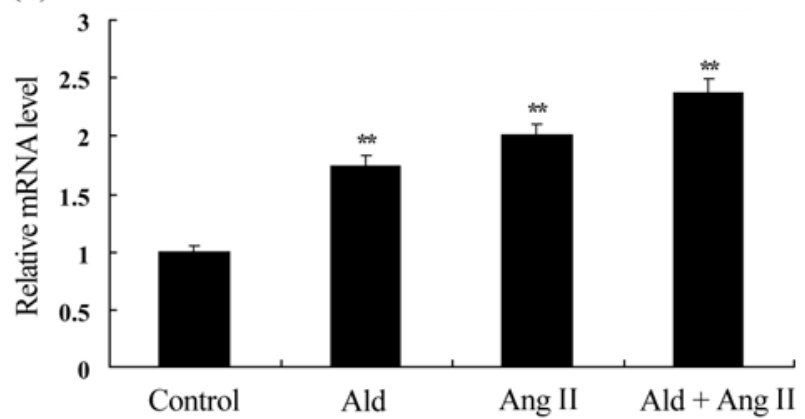

Fig. 1. Induction of PAI-1 mRNA with aldosterone and/or Ang II in mesangial cells. (A) Typical RT-PCR results. Lane 1: Marker; lane 2: untreated control; lane 3: treatment with $100 \mathrm{nM}$ aldosterone; lane 4: treatment with $100 \mathrm{nM}$ Ang II; 5: treatment with aldosterone $(100 \mathrm{nM})+$ Ang II $(100 \mathrm{nM})$. (B) Relative mRNA level of PAI-1, which are normalized with GAPDH levels. $* p<0.05$ versus control; ${ }^{* *} p<0.01$ versus control.

combination of aldosterone and Ang II for $24 \mathrm{~h}$. The effects of aldosterone and Ang II on PAI-1 mRNA expression were analyzed by RT-PCR and shown in Fig. 1. Aldosterone at $100 \mathrm{nM}$ up-regulated PAI-1 mRNA expression by 1.8 -fold compared to the control at $24 \mathrm{~h}$. Ang II also up-regulated PAI1 mRNA expression by 2-fold that of control. Furthermore, exposure of the cells to combination of aldosterone and Ang II resulted a 2.3-fold increase in the expression of PAI-1 mRNA.

After 48-h incubation, in comparison to control group $(120.9 \pm 23.78 \mathrm{pg} / \mathrm{ml})$ both aldosterone and Ang II increased PAI-1 protein secretion by mesangial cells into media to 241.2 $\pm 26.3 \mathrm{pg} / \mathrm{ml}$ and $251.7 \pm 20.3 \mathrm{pg} / \mathrm{ml}$ respectively (Fig 2). Cotreatment of aldosterone with Ang II further increased PAI-1 protein secretion to $293.5 \pm 44.7 \mathrm{pg} / \mathrm{ml}$.

Concentration dependence of effect of aldosterone on induction of PAI-1 mRNA. Aldosterone of the concentrations of $10^{-5}, 10^{-6}, 10^{-7}, 10^{-8}, 10^{-9}, 10^{-10}, 10^{-11} \mathrm{~mol} / 1$ was added in mesangial cells, and incubation time was $24 \mathrm{~h}$. Aldosterone

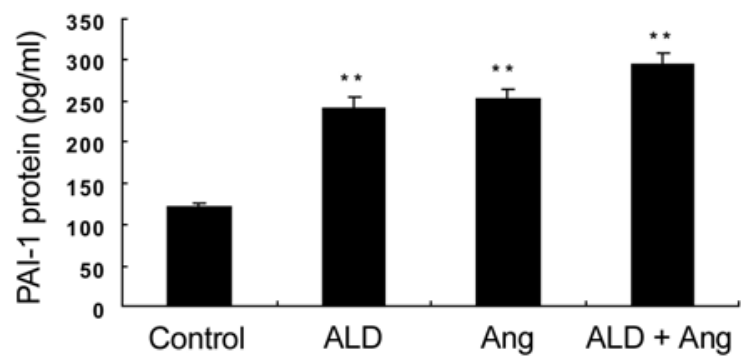

Fig. 2. Effect of aldosterone, Ang II or aldosterone + Ang II on PAI-1 protein espression by mesangial cells. $* p<0.05$ versus control; $* * p<0.01$ versus control.
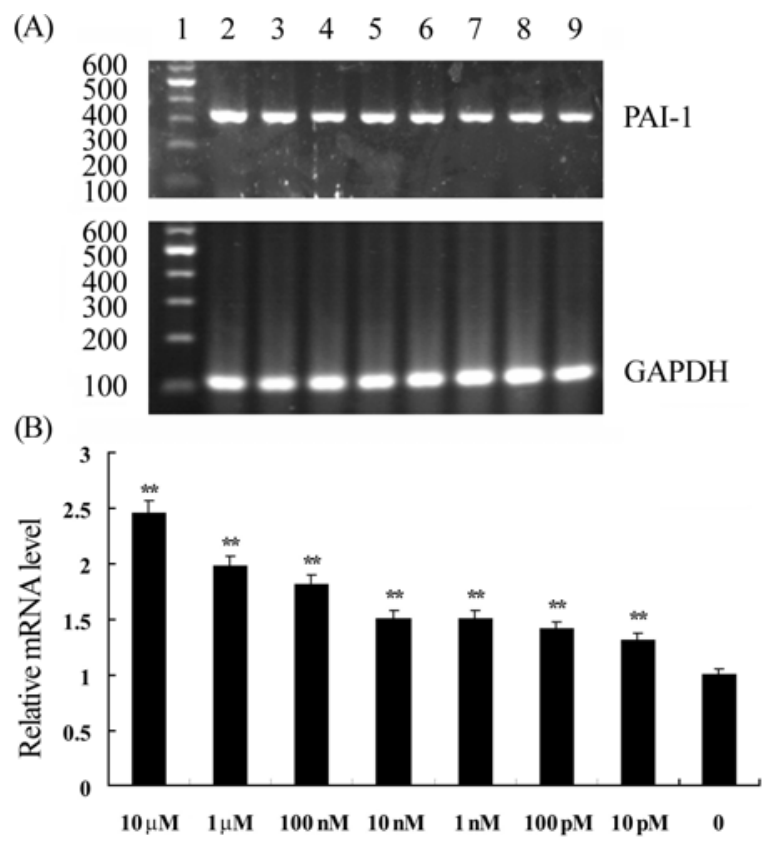

Fig. 3. Concentration dependence of effect of aldosterone on induction of PAI-1 mRNA. (A) Typical RT-PCR results. Lane 1: Marker; lanes 2, 3, 4, 5, 6, 7, 8 showed the results after treatment with aldosterone at the concentration of $10 \mu \mathrm{M}, 1 \mu \mathrm{M}$, $100 \mathrm{nM}, 10 \mathrm{nM}, 1 \mathrm{nM}, 100 \mathrm{pM}, 10 \mathrm{pM}$ respectively; lane 9: untreated control; (B) Relative mRNA level of PAI-1, which are normalized with GAPDH levels. $*_{p}<0.05$ versus control; ${ }^{* *} p<0.01$ versus control.

caused a concentration-dependent increase in PAI-1 mRNA expression, as demonstrated in Fig. 3. Maximal induction of PAI-1 mRNA was observed at the highest dose of $10^{-5} \mathrm{M}$ aldosterone.

Time-course of PAI-1 mRNA expression induced by aldosterone. In this experiment, the aldosterone concentration was $100 \mathrm{nmol} / \mathrm{l}$. After being deprived of serum for $24 \mathrm{~h}$, mesangial cells were incubated with aldosterone $(100 \mathrm{nM})$ for $0,0.5,1,2,4,6,8$ and $24 \mathrm{~h}$ respectively. Then total RNA was extracted from cell lysate and subjected to RT-PCR analysis. Enhancement of PAI-1 mRNA expression was seen after $4 \mathrm{~h}$ of exposure to aldosterone but not after shorter exposure (Fig. 4). 
(A)

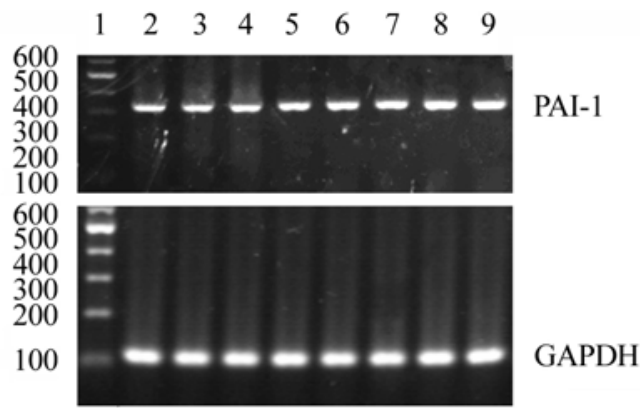

(B)

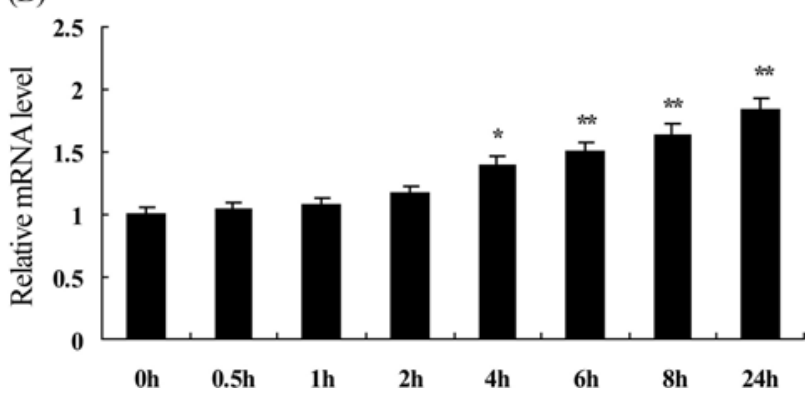

Fig. 4. Time-course of PAI-1 mRNA expression induced by aldosterone. PAI-1 mRNA was analyzed by RT-PCR as described in Methods. Time point 0 represents the control. (A) Typical RTPCR results. Lane 1: Marker; lanes 2, 3, 4, 5, 6, 7, 8, 9 showed the results after treatment with $100 \mathrm{nM}$ aldosterone for $0,0.5,1$, $2,4,6,8,24 \mathrm{~h}$ repectively. (B) Relative mRNA level of PAI-1, which are normalized with GAPDH levels. $* p<0.05$ versus control; $* * p<0.01$ versus control.

Effects of aldosterone in the absence or presence of spironolactone on cellular ROS and Expression of TGF- $\beta_{1}$ in mesangial cells. Intracellular DCF-sensitive ROS was visualized by a confocal microscopy, and the results were analyzed by Leica confocal software program. TGF- $\beta_{1}$ in conditioned media was quantitatively measured by ELISA method. The basal cellular ROS level was 3.59. After mesangial cells were incubated with $100 \mathrm{nM}$ or $1 \mu \mathrm{M}$ aldosterone for $24 \mathrm{~h}$, ROS level in cells increased significantly 4.77 -fold and 4.87-fold respectively compared to the control (Fig. 5), and TGF- $\beta_{1}$ secretion increased from $75.11 \pm 23.37 \mathrm{pg} / \mathrm{ml}$ to $147.09 \pm 26.51 \mathrm{pg} / \mathrm{ml}$ and $183.05 \pm 24.61 \mathrm{pg} / \mathrm{ml}$ respectively (Fig. 6).

But if mesangial cells were pretreated with $1 \mathrm{nM}$ spironolactone for $3 \mathrm{~h}$ before the addition of aldosterone of the concentrations of $100 \mathrm{nM}$ or $1 \mu \mathrm{M}$, spironolactone at $1 \mathrm{nM}$ effectively inhibited aldosterone-induced TGF- $\beta_{1}$ secretion and cellular ROS to normal level. Spironolactone did not alter the basal TGF- $\beta_{1}$ secretion and cellular ROS (Fig. 6).

Effects of TGF- $\beta_{1}$ neutralizing antibody and NAC on aldosterone-induced PAI-1 mRNA and protein expression. This study examined whether TGF- $\beta_{1}$ neutralizing antibody and NAC inhibited aldosterone-induced PAI-1 mRNA and protein expression. Neither $100 \mu \mathrm{g} / \mathrm{ml}$ TGF- $\beta_{1}$ neutralizing antibody nor $5 \mathrm{mM}$ NAC alone increased PAI-1 mRNA (Fig. 7) and protein expression (Fig. 8) by mesangial cells compared to the control value. But TGF- $\beta_{1}$ neutralizing antibody or NAC effectively decreased aldosterone-induced PAI-1 mRNA expression $30 \%$ and $32 \%$ respectively (Fig. 7 ).

TGF- $\beta_{1}$ neutralizing antibody or NAC also decreased aldosterone-induced PAI-1 protein expression to $190.7 \pm 29.2$ $\mathrm{pg} / \mathrm{ml}$ and $184.1 \pm 33.4 \mathrm{pg} / \mathrm{ml}$ respectively (Fig. 8). However, neither TGF- $\beta_{1}$ neutralizing antibody nor NAC alone could inhibit aldosterone-induced PAI-1 mRNA (Fig. 7) and protein expression (Fig. 8) to normal level at $24 \mathrm{~h}$.

Effects of spironolactone on aldosterone-induced PAI$1 \mathrm{mRNA}$ and protein expression by mesangial mells. Effects of spironolactone on aldosterone-induced PAI-1 mRNA expression were analyzed by semi-quantitative RT-PCR. $1 \mathrm{nM}$ Spironolactone efficiently inhibited induction of PAI-1 mRNA by $100 \mathrm{nM}$ or $1 \mu \mathrm{M}$ aldosterone (Fig. 9).

$1 \mathrm{nM}$ Spironolactone also markedly reduced synthesis of PAI-1 protein stimulated by aldosterone of $100 \mathrm{nM}$ or $1 \mu \mathrm{M}$ to control levels. Spironolactone did not affect basal PAI-1 protein synthesis (Fig. 10).

\section{Discussion}

Aldosterone plays a pivotal role in electrolyte and fluid homeostasis and thus control of blood pressure (Booth et al., 2002). If we investigated the effects of aldosterone on production of PAI-1 by aldosterone-infused rats, we could not avoid hypertension or other disorder induced by aldosterone. These factors maybe influence PAI-1 mRNA expression and protein synthesis (Fogari and Zoppi, 2005; Kuriyama et al., 2005). The in vitro study do not affect blood press and can exclude the possibility that hemodynamic changes influence the nonhemodynamic effect of aldosterone on production of PAI-1.

In agreement with previous study(Motojima et al., 2000), Ang II induced an increase in the expression of PAI-1 mRNA and protein by cultured mesangial cells in our study. The upregulation of PAI-1 co-treated by aldosterone with Ang II was more greater than that treated by Ang II alone, which suggested aldosterone together with Ang II may produce profound pro-fibrotic effects. But we also demonstrate that aldosterone can up-regulate PAI-1 mRNA and protein expression by renal mesangial cells, which occurred in absence of Ang II. Furthermore, aldosterone increased PAI-1 mRNA expression in a concentration-dependent manner. In this report, we provide direct evidence that aldosterone could stimulate production of PAI-1 by renal mesangial cells independently of Ang II, which has previously been shown to mediate the effect of aldosterone.

Aldosterone significantly increased DCF-sensitive cellular ROS in mesangial cells after mesangial cells were incubated with aldosterone for $24 \mathrm{~h}$. Our results also are supported by the report that other kinds of cells, such as peripheral blood 


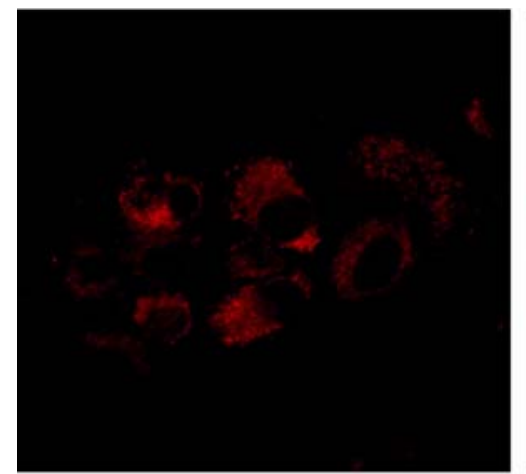

Control

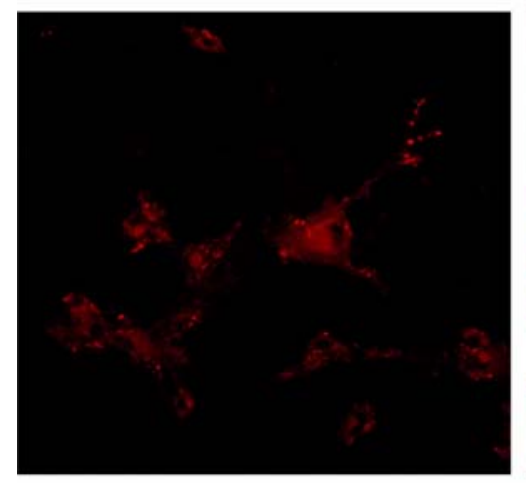

Mesangial cells + aldosterone (100 nM)

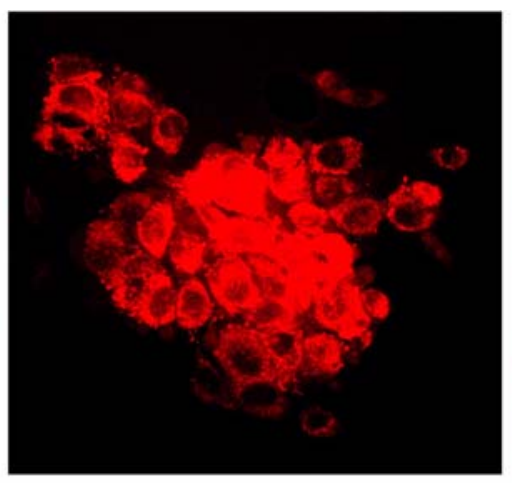

Mesangial cells + aldosterone $(1 \mu \mathrm{M})$

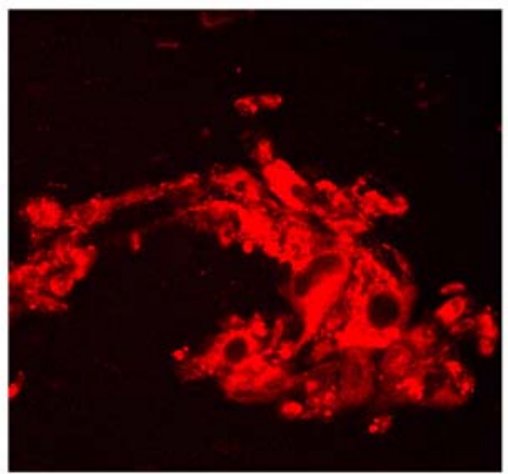

Mesangial cells + aldosterone $(100 \mathrm{nM})$ + spironolance $(1 \mathrm{nM})$

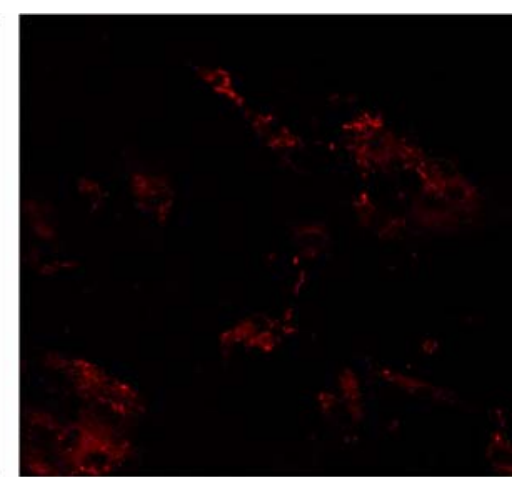

Mesangial cells + aldosterone $(1 \mu \mathrm{M})$ + spironolance $(1 \mathrm{nM})$

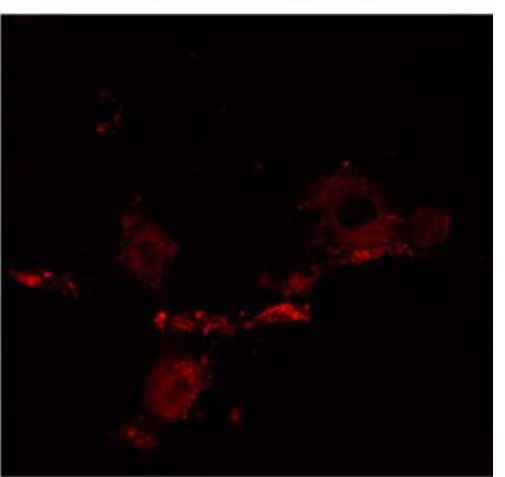

Mesangial cells + spironolance $(1 \mathrm{nM})$

(A)

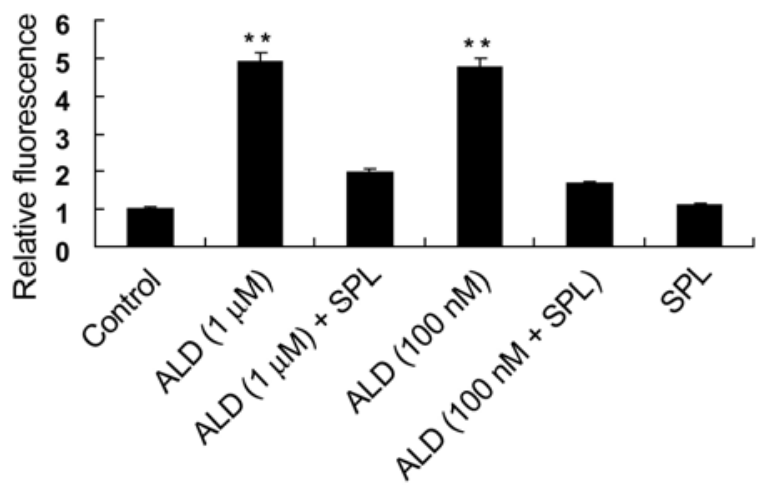

(B)

Fig. 5. Effects of aldosterone in the presence or absence of spironolactone on reactive oxygen species in mesangial cells. (A) Representative image of fluorescent signals generated from composite images obtained by confocal microscopy of mesangial cells pretreated with the radical probe $\mathrm{CM}-\mathrm{H}_{2}$ DCFDA for $45 \mathrm{~min}$. (B) Results of cellular ROS analyzed by Leica Confocal Software program are graphically shown. Lane 1: Control; lane 2: Mesangial cells + aldosterone $(1 \mu \mathrm{M})$; lane 3 : Mesangial cells + aldosterone $(1 \mu \mathrm{M})$ + spironolance $(1 \mathrm{nM})$; lane 4: Mesangial cells + aldosterone $(100 \mathrm{nM})$; lane 5: Mesangial cells + aldosterone $(100 \mathrm{nM})+$ spironolance $(1 \mathrm{nM})$; lane 6: Mesangial cells + spironolance $(1 \mathrm{nM}) . * p<0.05$ versus control; $* * p<0.01$ versus control.

monocytes (Fiebeler and Luft, 2005) and vascular smooth muscle cells (Fiebeler and Luft, 2005), can also be influenced by aldosterone to produce ROS. It has long been recognized that ROS are harmful for cells, mainly because they injure lipids, proteins, and nucleic acids, which leads to structural and functional impairments (Rodrigo and Bosco, 2006). The glomerulus is considerably more sensitive to oxidative injuries than other nephron segments. Oxidative stress may alter the structure and function of the glomerulus because of the effect of ROS on mesangial cells (Rodrigo and Bosco, 2006). In a 


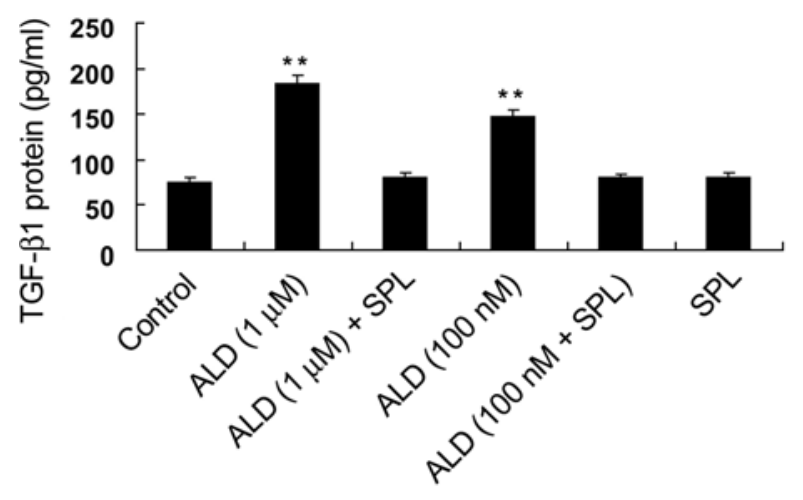

Fig. 6. Effects of aldosterone in the presence or absence of spironolactone on Expression of TGF- $\beta_{1}$ by Mesangial Cells. Lane 1: Control; lane 2: Mesangial cells + aldosterone $(1 \mu \mathrm{M})$; lane 3: Mesangial cells + aldosterone $(1 \mu \mathrm{M})+$ spironolance $(1 \mathrm{nM})$; lane 4: Mesangial cells + aldosterone $(100 \mathrm{nM})$; lane 5: Mesangial cells + aldosterone $(100 \mathrm{nM})+$ spironolance $(1 \mathrm{nM}) ;$ lane 6 : Mesangial + spironolance $(1 \mathrm{nM}) .{ }^{*} p<0.05$ versus control; ${ }^{* *} p<$ 0.01 versus control.

word, as PAI-1 does, ROS up-regulated by aldosterone in mesangial cells may also implicate in the pathogenesis of glomerular sclerosis.

Substantial clinical and experimental evidences suggest that TGF- $\beta_{1}$ is the key mediator of glomerular fibrosis (Ziyadeh et al., 1998; Peters et al., 1999). In vivo studies have demonstrated that aldosterone could evoke TGF- $\beta_{1}$ in the kidney, and this action contributed to aldosterone-dependent renal injury (Feria et al., 2003; Fujisawa et al., 2004; Juknevicius et al., 2004). The present study also shows that aldosterone significantly up-regulates expression of TGF- $\beta_{1}$ by mesangial cells.

TGF- $\beta_{1}$ promotes glomerular fibrosis not only by enhancing ECM synthesis, but also by decreasing ECM degradation. TGF- $\beta_{1}$ degrades and turnovers the ECM mainly through stimulating the synthesis of PAI-1 by mesangial cells (Tomooka et al., 1992; Baricos et al., 1999) and PAI-1 gene deficiency can attenuate TGF- $\beta_{1}$-induced interstitial ECM deposition (Krag et al., 2005). TGF- $\beta_{1}$ is a potent inducer of PAI-1 gene expression (Wilson et al., 1993; Dennler et al., 1998). ROS have close relationship with upregulation of PAI-1 expression too (Cheng et al., 1996; Du et al., 2000; Zhao et al., 2001; Ha, Lee, 2005). The promoter region of PAI-1 gene contains binding sites for several redox sensitive transcription factors such as Sp1, AP-1, and NF- $\kappa$ B (Rerolle et al., 2000). Reports that both TGF- $\beta_{1}$ and ROS increases PAI-1 expression prompted us to investigate whether ROS and TGF- $\beta_{1}$ mediate aldosteroneinduced PAI-1 up-regulation in mesangial cells. In our study, PAI-1 mRNA and protein expression were significantly reduced when mesangial cells were coincubated with aldosterone and antioxidant NAC for $24 \mathrm{~h}$, but could not decrease to normal level. We also explored the role of TGF- $\beta_{1}$ in the process that aldosterone induced the production of PAI- 1 by TGF- $\beta_{1}$ neutralizing antibody treatment of mesangial cells. However, TGF- $\beta_{1}$ neutralizing antibody only partially decreased this
(A)

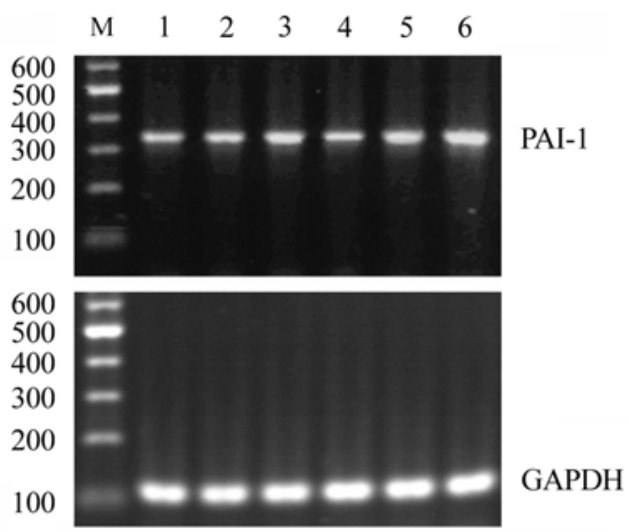

(B)

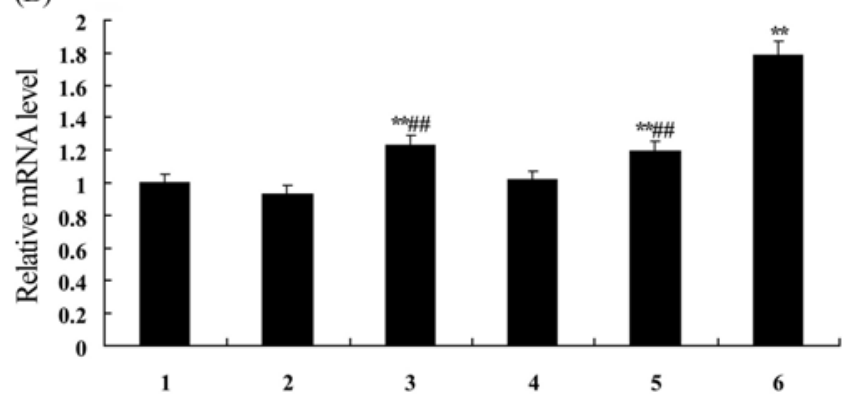

Fig. 7. Effects of TGF- $\beta_{1}$ neutralizing antibody and NAC on aldosterone-induced PAI-1 mRNA expression. (A) Typical RTPCR results. Lane M: Marker; lane 1: Control; lane 2: Mesangial cells + anti-TGF- $\beta_{1}$ antibody; lane 3 : Mesangial cells + aldosterone + anti- TGF- $\beta_{1}$ antibody; lane 4: Mesangial cells + NAC; lane 5: Mesangial cells + aldosterone $+\mathrm{NAC}$; lane 6: Mesangial cells + aldosterone. (B) Relative mRNA level of PAI-1, which are normalized with GAPDH levels. ${ }^{*} p<0.05$ versus control; $* * p<0.01$ versus control; ${ }^{\#} p<0.05$ versus Mesangial cells + aldosterone; ${ }^{\# \#} p<0.01$ versus Mesangial cells + aldosterone.

aldosterone-stimulated PAI-1 expression in mesangial cells just as NAC did. This finding is also in good agreement with results from animal experiments (Ma et al., 2003). Therefore, ROS or TGF- $\beta_{1}$ induced by incubation of mesangial cells with aldosterone play an important role in aldosterone-induced PAI-1 expression, but aldosterone can induce PAI-1 expression through a TGF- $\beta_{1}$ - or ROS-independent pathway.

Besides the increase of expression of TGF- $\beta_{1}$ and cellular ROS, aldosterone also has been shown to increase tissue ACE activity, a further increase in angiotensin II (Krug et al., 2002).Furthermore, Ang II can up-regulate PAI-1 expression in mesangial cells as well (Kagami et al., 1997). Perhaps, there are several cell factors or pathways involved in aldosterone-induced PAI-1 generation in mesangial cells, and ROS or TGF- $\beta_{1}$ was not the exclusive pathway of PAI-1 expression induced by aldosterone in mesangial cells. The function and the interrelationship of cell factors induced by aldosterone in upregulating PAI-1 expression are still to be studied.

Aldosterone has two modes of actions: the genomic actions of aldosterone and the nongenomic action of aldosterone. The classical actions of aldosterone are mediated by intracellular 


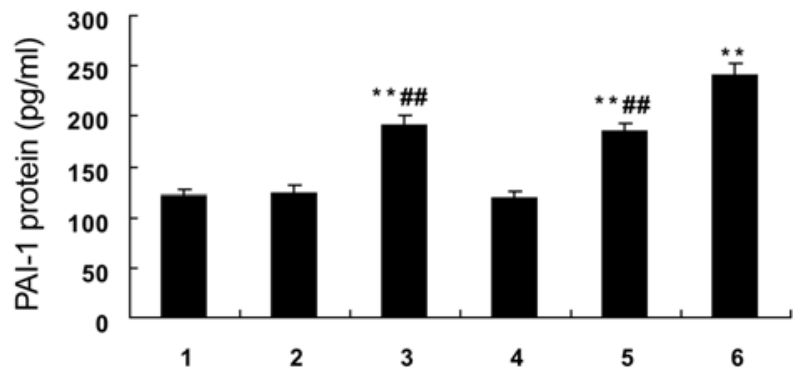

Fig. 8. Effects of TGF- $\beta_{1}$ neutralizing antibody and NAC on aldosterone -induced PAI-1 protein expression. Lane 1: Control; lane 2: Mesangial cells + anti-TGF- $\beta_{1}$ antibody; lane 3 : Mesangial cells + aldosterone + anti- TGF- $\beta_{1}$ antibody; lane 4: Mesangial cells + NAC; lane 5: Mesangial cells + aldosterone + NAC; lane 6: Mesangial cells + aldosterone. ${ }^{*} p<0.05$ versus control; $* * p<0.01$ versus control; ${ }^{\#} p<0.05$ versus Mesangial cells + aldosterone; ${ }^{\#} p<0.01$ versus Mesangial cell + aldosterone.

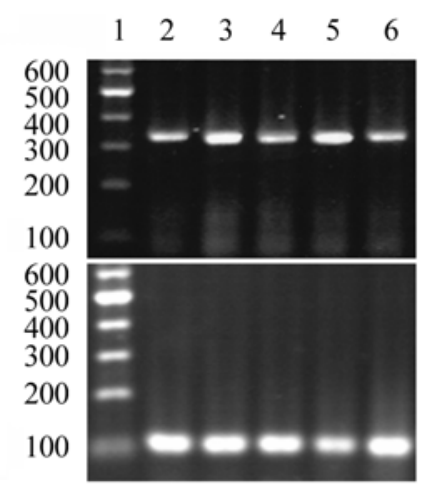

(B)

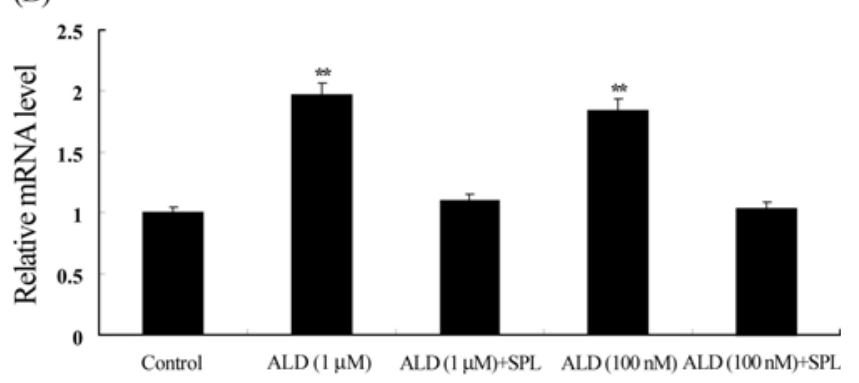

Fig. 9. Effects of spironolance on aldosterone-induced PAI1 mRNA expression by Mesangial Cells. (A) Typical RT-PCR results. Lane 1: Marker; lane 2: Control; lane 3: Mesangial cells + $1 \mu \mathrm{M}$ aldosterone; lane 4: Mesangial cells $+1 \mu \mathrm{M}$ aldosterone + $1 \mathrm{nM}$ spironolance; lane 5: Mesangial cells + Mesangial cells + $100 \mathrm{nM}$ aldosterone; lane 6: Mesangial cells $+100 \mathrm{nM}$ aldosterone $+1 \mathrm{nM}$ spironolance. (B) Relative mRNA level of PAI-1, which is normalized with GAPDH levels. ${ }^{*} p<0.05$ versus control; $* * p<0.01$ versus control.

receptors that translocate to the nucleus upon ligand binding. Aldosterone binds to intracellular receptors and subsequently modulates transcription and protein synthesis, thus triggering

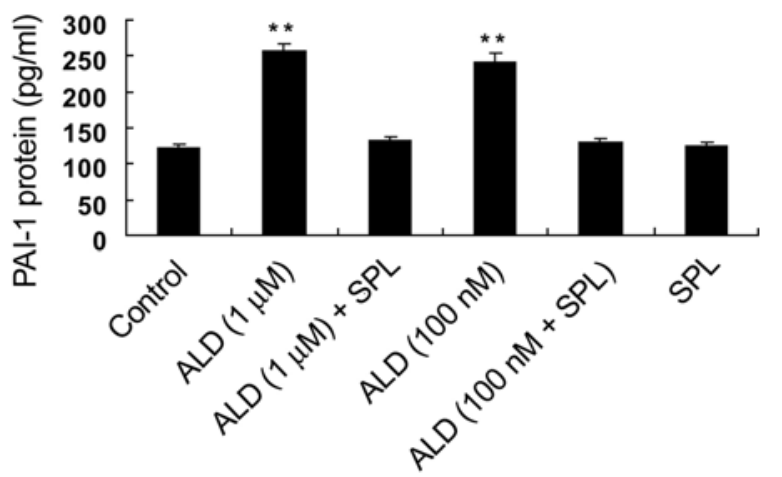

Fig. 10. Effects of spironolance on aldosterone-induced PAI-1 protein expression by Mesangial Cells. Lane 1: Control; lane 2: Mesangial cells $+1 \mu \mathrm{M}$ aldosterone; lane 3: Mesangial cells + $1 \mu \mathrm{M}$ aldosterone $+1 \mathrm{nM}$ spironolance; lane 4: Mesangial cells + $100 \mathrm{nM}$ aldosterone; lane 5: Mesangial cells $+100 \mathrm{nM}$ aldosterone $+1 \mathrm{nM}$ spironolance; lane 6: Mesangial cells $+1 \mathrm{nM}$ spironolance ${ }^{*} p<0.05$ versus control; $* * p<0.01$ versus control.

genomic events finally responsible for delayed effects. The genomic actions of aldosterone mandate changes in gene expression, which results in a substantial latent period (from 0.5 to $1.0 \mathrm{~h}$ ) prior to overt changes in cellular activity. The genomic actions of aldosterone can be blocked by MR antagonist. The nongenomic action of aldosterone is considered to be independent of direct effects on gene expression which results in rapid responses $(<15 \mathrm{~min})$. These rapid responses are not sensitive to mineralocorticoid receptor antagonist (Booth et al., 2002). Time-course studies indicated that Enhancement of PAI-1 mRNA expression was seen $4 \mathrm{~h}$ later when mesangial cells exposed to aldosterone but not after shorter exposure, and sensitivity to spironolactone of the PAI1 induction are entirely consistent with being mineralocorticoid receptor-mediatated events. Spironolactone, a mineralocorticoid receptor antagonist, also effectively inhibited TGF- $\beta_{1}$ expression and cellular ROS induced by aldosterone to normal level at the 24th hour. Taken together, these data clearly demonstrate that aldosterone increases generation of PAI-1, TGF- $\beta_{1}$ and cellular ROS via activation of mineralocorticoid receptor, which may contribute the pathophysiology of aldosteroneinduced glomerulosclerosis. Our study also implies that therapy with mineralocorticoid receptor antagonists may have a therapeutic potential for glomerulosclerosis.

In conclusion, our present data show that aldosterone can increase PAI-1 mRNA and protein expression by cultured mesangial cells which have been shown to be a key regulator of fibrinolysis and ECM. That induction of PAI-1 expression by aldosterone is independent of aldosterone-induced increase in expression of TGF- $\beta_{1}$ or cellular ROS. The effects on PAI-1, TGF- $\beta_{1}$ and cellular ROS generation were markedly attenuated by spironolactone, which demonstrate that mineralocorticoid receptor may play a role in mediating these effects of aldosterone. 


\section{References}

Aldigier, J. C., Kanjanbuch, T., Ma, L. J., Brown, N. J. and Fogo A. B. (2005) Regression of existing glomerulosclerosis by inhibition of aldosterone. J. Am. Soc. Nephrol. 16, 3306-3314.

Baricos, W. H., Cortez, S. L., Deboisblanc, M. and Xin, S. (1999) Transforming growth factor-beta is a potent inhibitor of extracellular matrix degradation by cultured human mesangial cells. J. Am. Soc. Nephrol. 10, 790-795.

Booth, R. E., Johnson, J. P. and Stockand, J. D. (2002) Aldosterone. Adv. Physiol. Educ. 26, 8-20.

Brown, N. J., Agirbasli, M. A., Williams, G. H., Litchfield, W. R. and Vaughan, D. E. (1998) Effect of activation and inhibition of the renin-angiotensin system on plasma PAI-1. Hypertension 32, 965-971.

Brown, N. J., Kim, K. S., Chen, Y. Q., Blevins, L. S., Nadeau, J. H., Meranze, S. G. and Vaughan, D. E. (2000) Synergistic effect of adrenal steroids and angiotensin II on plasminogen activator inhibitor-1 production. J. Clin. Endocrinol. Metab. 85, 336-344.

Brown, N. J., Nakamura, S., Ma, L., Nakamura, I., Donnert, E., Freeman, M., Vaughan, D. E. and Fogo, A. B. (2000) Aldosterone modulates plasminogen activator inhibitor-1 and glomerulosclerosis in vivo. Kidney Int. 58, 1219-1227.

Cheng, J. J., Chao, Y. J., Wung, B. S. and Wang, D. L. (1996) Cyclic strain-induced plasminogen activator inhibitor-1 (PAI-1) release from endothelial cells involves reactive oxygen species. Biochem. Biophys. Res. Commun. 225, 100-105.

Dennler, S., Itoh, S., Vivien, D., ten Dijke, P., Huet, S. and Gauthier, J. M. (1998) Direct binding of Smad3 and Smad4 to critical TGF beta-inducible elements in the promoter of human plasminogen activator inhibitor-type 1 gene. $E M B O J$. 17, 3091-3100.

Du, X. L., Edelstein, D., Rossetti, L., Fantus, I. G., Goldberg, H., Ziyadeh, F., Wu, J. and Brownlee, M. (2000) Hyperglycemiainduced mitochondrial superoxide overproduction activates the hexosamine pathway and induces plasminogen activator inhibitor-1 expression by increasing Sp1 glycosylation. Proc. Natl. Acad. Sci. USA 97, 12222-12226.

Eddy, A. A. (2000) Molecular basis of renal fibrosis. Pediatr Nephrol. 15, 290-301.

Eddy, A. A. (2002) Plasminogen activator inhibitor-1 and the kidney. Am. J. Physiol. Renal. Physiol. 283, 209-220.

Feria, I., Pichardo, I., Juarez, P., Ramirez, V., Gonzalez, M. A., Uribe, N., Garcia-Torres, R., Lopez-Casillas, F., Gamba, G. and Bobadilla, N. A. (2003) Therapeutic benefit of spironolactone in experimental chronic cyclosporine A nephrotoxicity. Kidney Int. 63, 43-52.

Fiebeler, A. and Luft, F. C. (2005) The mineralocorticoid receptor and oxidative stress. Heart Fail Rev. 10, 47-52.

Fogari, R. and Zoppi, A. (2005) Is the effect of antihypertensive drugs on platelet aggregability and fibrinolysis clinically relevant?. Am. J. Cardiovasc. Drugs 5, 211-223.

Fujisawa, G., Okada, K., Muto, S., Fujita, N., Itabashi, N., Kusano, E. and Ishibashi, S. (2004) Spironolactone prevents early renal injury in streptozotocin-induced diabetic rats. Kidney Int. 66, 1493-1502.

Ha, H. and Lee, H. B. (2005) Reactive oxygen species amplify glucose signalling in renal cells cultured under high glucose and in diabetic kidney. Nephrology (Carlton) 10, 7-10.
Hollenberg, N. K. (2004) Aldosterone in the development and progression of renal injury. Kidney Int. 66, 1-9.

Jiang, Z., Seo, J. Y., Ha, H., Lee, E. A., Kim, Y. S., Han, D. C., Uh, S. T., Park, C. S. and Lee, H. B. (2003) Reactive oxygen species mediate TGF-beta1-induced plasminogen activator inhibitor-1 upregulation in mesangial cells. Biochem. Biophys. Res. Commun. 309, 961-966.

Juknevicius, I., Segal, Y., Kren, S., Lee, R. and Hostetter, T. H. (2004) Effect of aldosterone on renal transforming growth factor-beta. Am. J. Physiol. Renal. Physiol. 286, 1059-1062.

Kagami, S., Kuhara, T., Okada, K., Kuroda, Y., Border, W. A. and Noble, N. A. (1997) Dual effects of angiotensin II on the plasminogen/plasmin system in rat mesangial cells. Kidney Int. 51, 664-671.

Krag, S., Danielsen, C. C., Carmeliet, P., Nyengaard, J. and Wogensen, L. (2005) Plasminogen activator inhibitor-1 gene deficiency attenuates TGF-beta1-induced kidney disease. Kidney Int. 68, 2651-2666.

Krug, A. W., Schuster, C., Gassner, B., Freudinger, R., Mildenberger, S., Troppmair, J. and Gekle, M. (2002) Human epidermal growth factor receptor-1 expression renders Chinese hamster ovary cells sensitive to alternative aldosterone signaling. J. Biol. Chem. 277, $45892-45897$.

Kuriyama, S., Otsuka, Y., Iida, R., Matsumoto, K., Tokudome, G. and Hosoya, T. (2005) Morning blood pressure predicts hypertensive organ damage in patients with renal diseases: effect of intensive antihypertensive therapy in patients with diabetic nephropathy. Intern. Med. 44, 1239-1246.

Lai, L. Y., Gu, Y., Chen, J., Yu, S. Q., Ma, J., Yang, H. C. and Lin, S. Y. (2003) Production of aldosterone by rat mesangial cell and the accumulation of extracellular matrix induced by aldosterone. Zhonghua Yi Xue Za Zhi. 83, 1900-1905.

Lee, E. A., Seo, J. Y., Jiang, Z., Yu, M. R., Kwon, M. K., Ha, H. and Lee, H. B. (2005) Reactive oxygen species mediate high glucose-induced plasminogen activator inhibitor-1 up-regulation in mesangial cells and in diabetic kidney. Kidney Int. 67, 17621771.

Lee, H. B., Yu, M. R., Yang, Y., Jiang, Z. and Ha, H. (2003) Reactive oxygen species-regulated signaling pathways in diabetic nephropathy. J. Am. Soc. Nephrol. 14, 241-245.

Ma, L. J., Yang, H., Gaspert, A., Carlesso, G., Barty, M. M., Davidson, J. M., Sheppard, D. and Fogo, A. B. (2003) Transforming growth factor-beta-dependent and -independent pathways of induction of tubulointerstitial fibrosis in beta6(-/-) mice. Am. J. Pathol. 163, 1261-1273.

Mignatti, P. (1995) Extracellular matrix remodeling by metalloproteinases and plasminogen activators. Kidney Int. Suppl. 49, 12-14.

Miric, G., Dallemagne, C., Endre, Z., Margolin, S., Taylor, S. M. and Brown, L. (2001) Reversal of cardiac and renal fibrosis by pirfenidone and spironolactone in streptozotocin-diabetic rats. Br. J. Pharmacol. 133, 687-694.

Miyata, K., Rahman, M., Shokoji, T., Nagai, Y., Zhang, G. X., Sun, G. P., Kimura, S., Yukimura, T., Kiyomoto, H., Kohno, M., Abe, Y. and Nishiyama, A. (2005) Aldosterone stimulates reactive oxygen species production through activation of NADPH oxidase in rat mesangial cells. J. Am. Soc. Nephrol. 16, 2906-2912.

Motojima, M., Ando, T. and Yoshioka, T. (2000) Sp1-like activity mediates angiotensin-II-induced plasminogen-activator inhibitor 
type-1 (PAI-1) gene expression in mesangial cells. Biochem. $J$. 349, 435-441.

Nishiyama, A. and Abe, Y. (2004) Aldosterone and renal injury. Nippon Yakurigaku Zasshi. 124, 101-109.

Nishiyama, A. and Abe, Y. (2006) Molecular mechanisms and therapeutic strategies of chronic renal injury: renoprotective effects of aldosterone blockade. J. Pharmacol. Sci. 100, 9-16.

Nishiyama, A., Yao, L., Fan, Y., Kyaw, M., Kataoka, N., Hashimoto, K., Nagai, Y., Nakamura, E., Yoshizumi, M., Shokoji, T., Kimura, S., Kiyomoto, H., Tsujioka, K., Kohno, M., Tamaki, T., Kajiya, F. and Abe, Y. (2005) Involvement of aldosterone and mineralocorticoid receptors in rat mesangial cell proliferation and deformability. Hypertension 45, 710-716.

Peters, H., Border, W. A. and Noble, N. A. (1999) Targeting TGFbeta overexpression: maximizing the antifibrotic actions of angiotensin II blockade in anti-Thy1 glomerulonephritis. Nephrol. Dial. Transplant. 14, 22-23.

Rerolle, J. P., Hertig, A., Nguyen, G., Sraer, J. D. and Rondeau, E. P. (2000) Plasminogen activator inhibitor type 1 is a potential target in renal fibrogenesis. Kidney Int. 58, 1841-1850.

Rodrigo, R. and Bosco, C. (2006) Oxidative stress and protective effects of polyphenols: Comparative studies in human and rodent kidney. A review. Comp. Biochem. Physiol. C. Toxicol. Pharmacol. 142, 317-327.

Sato, A., Hayashi, K., Naruse, M. and Saruta, T. (2003) Effectiveness of aldosterone blockade in patients with diabetic nephropathy. Hypertension 41, 64-68.

Schnaper, H. W. (1995) Balance between matrix synthesis and degradation: a determinant of glomerulosclerosis. Pediatr. Nephrol. 9, 104-111.

Stetler-Stevenson, W. G. (1996) Dynamics of matrix turnover during pathologic remodeling of the extracellular matrix. Am. J. Pathol. 148, 1345-1350.

Tomooka, S., Border, W. A., Marshall, B. C. and Noble, N. A. (1992) Glomerular matrix accumulation is linked to inhibition of the plasmin protease system. Kidney Int. 42, 1462-1469.

Vassalli, J. D., Sappino, A. P. and Belin, D. (1991) The plasminogen activator/plasmin system. J. Clin. Invest. 88, 1067-1072.

Vaughan, D. E. (2001) Angiotensin, fibrinolysis, and vascular homeostasis. Am. J. Cardiol. 87, 18-24.

Wilson, H. M., Reid, F. J., Brown, P. A., Power, D. A., Haites, N. E. and Booth, N. A. (1993) Effect of transforming growth factor-beta 1 on plasminogen activators and plasminogen activator inhibitor-1 in renal glomerular cells. Exp. Nephrol. 1, 343-350.

Zhao, W., Spitz, D. R., Oberley, L. W. and Robbins, M. E. (2001) Redox modulation of the pro-fibrogenic mediator plasminogen activator inhibitor-1 following ionizing radiation. Cancer Res. 61, 5537-5543.

Ziyadeh, F. N., Han, D. C., Cohen, J. A., Guo, J. and Cohen, M. P. (1998) Glycated albumin stimulates fibronectin gene expression in glomerular mesangial cells: involvement of the transforming growth factor-beta system. Kidney Int. 53, 631638. 